\title{
WHAT EXACTLY ARE WE TESTING WHEN WE CLAIM TO BE TESTING MOTHER-TONGUE COMMUNICATIVE COMPETENCE?
}

\author{
Norah Haussmanı - Human Sciences Research Council, Pretoria
}

\section{INTRODUCTION}

I am assuming that most of you are either linguists or representatives from various language professions, and as such, I am sure that you have all at some time or another wrestled with the question as to what it is that we are testing when we claim to be testing mother-tongue competence. I know that for me, even after twenty years in the profession, the concept remains as elusive as one's I.Q. To make matters worse, in more recent years, we have been confronted by the notion of "communicative competence".

As stated in my abstract, in the testing of mother-tongue competence it is vital to have a thorough understanding of what it means to be competent in one's mother-tongue. After all, before we can test anything, we nced to know what it is that we are attempting to measure. In the ensuing discussion I hope to highlight the fact that a teacher's understanding of what is meant by the terms "competence" or "communicative competence" is not the same as that of the general linguist. What the teacher sees as "competence" or "communicative competence", the general linguist labels "performance". Such differences in understanding often create confusion and dispute in decisions related to language testing.' Being actively involved in the testing of mother-tongue language at senior secondary level, I have become increasingly aware of such disputes - especially when it comes to discussions on the relatively new communicative approach to language testing. This bcing the case, I would like to state quite baldly that I regard the term "communicative competence" as a misleading and unnecessary substitute for "performance".

If one is not involved in the crucial judgements which need to be made when testing language 
- especially at matriculation level - perhaps the most crucial stage in one's education - then one could adopt the attitude of the irresponsible star-crossed lover, Juliet, and ask' "What's in a name...?" However, when decisions must be made which affect the lives of people, perhaps the more ironically cautious words of Humpty Dumpty warrant a thought:

"My name is Alice ..."

"It's a stupid name enough!" Humpty Dumpty interrupted impatiently. "What does it mean?"

"Must a name mean something?"

"Of course it must," Humpty Dumpty said with a short laugh. "My name means the shape I am - and a good handsome shape it is too. With a name like yours, you might be any shape, almost."

\section{Lewis Carroll - Through the Looking-Glass}

To get to the point, I will be devoting some time to discussing the difference in meaning of such names or terms as "competence", "communicative competence", "mother-tongue competence", and "performance". An attempt to clarify their meaning will, I think, highlight the contribution that the discoveries of the linguist can make to the solution of some of the problems which arise in the course of language testing. Before discussing the various terms, I would, however, like to briefly define the field of applied linguistics as, of all the linguistic disciplines, applied linguistics is the most closely related to language teaching.

\section{DEFINING THE FIELD OF APPLIED LINGUISTICS}

Unlike general linguistics, or psycholinguistics, for example, applied linguistics is - as its name implies - an activity. It is not a theoretical study. But, the important thing to note is that applied linguistics makes use of the findings of theoretical studies. The applied linguist is thus a consumer, or a user, but not a producer of theories. Language teaching is also an activity, but it is not the same activity as applied linguistics. As Pit Corder (1973) explains, "It is only when we interpret language teaching in the very broadest sense to include all the planning and decision-making which takes place outside the classroom, that there may be an 
element of applied linguistics in language teaching" (pp. 10-11).

A revicw of the literature reveals that the discipline of applied linguistics is, in some quarters, regarded as practically synonymous with "the study of second and foreign language teaching". In fact, it is precisely defined as such by Richards, Platt and Webber (1985, p. 15). However, 1 believe that applied linguistics must include the domain of mother-tongue teaching. After all, "mother-tongue competence" is the aim of second-language teaching. And then, because evaluation is such an integral part of teaching, a direct implication of the definition is that it must include the study of language testing. In fact, Alderson (1990) actually defines language testing as "an area of applied linguistics that combincs the exercise of professional judgement about language ... with empirical data about student performance and, by inference, their abilities" (p. 1).

\section{THE SIMILAR NATURE OF MOTHER-TONGUE COMPETENCE AND COMMUNICATIVE COMPETENCE}

Another point which I would like to stress at the outset is that, if I take into account various linguistic definitions of the term "communicative competence", then I cannot see the difference between it and "mother-tongue competence". This must sound very confusing in view of the fact that I opened by stating quite categorically that I regard "communicative competence" as an unwarranted substitute for "performance". But, as I progress, I hope you will follow my reasoning.

As is the case with "applied linguistics", the term "communicative competence" also seems to relate predominantly to second-language teaching. It is in fact, very difficult to come by any literature on "communicative conpetence" which does relate to mother-tongue language. However, I believe the second-language literature dealing with the concept is equally pertinent to mother-tongue competence, if not more so.

For the sake of brevity, I cite only one brief definition of communicative competence - that of Richards, Platt and Webber (1985) - but it is one with which most proponents of the 
notion seem to accord. Communicative competence is defined as "the ability not only to apply grammatical rules of a language in order to form grammatically correct sentences, but also to know when and where to use these sentences and to whom " (p.49). Now, were I to attempt a definition of "mother-tongue competence", it would probably read very similarly to this definition. But, ironically, although I make a claim for the almost identical nature of "mother-tongue competence" and "communicative competence", 1 somehow find it easier to grasp the essential difference between "mother-tongue competence" and "performance" than that between "communicative competence" and "performance". Perhaps this is because I accept Chomsky's (1965) distinction between "competence" and "performance". That is, his distinction between innate knowledge of a language (competence) as opposed to actual use of a language (performance).

The important point which I wish to stress is that when language teachers speak of testing their pupils' "competence" - be it "mother-tongue competence" or "comnunicative competence", I believe they are in fact, testing what many linguists - and especially disciples of Chomsky, would probably call "performance". After all, it seems inevitable that the association of "communication" with "competence" must bring in aspects of performance. In other words, when we talk about "communicative competence" in the context of language testing, it is difficult to escape the conclusion that we are talking about the "ability to perform".

According to Newmeyer (1983) it is Hymes who, in 1971, first coined the term "communicative competence" as "the most general term for the speaking and hearing capabilities of a person" (1971, p. 16, cited by Newmeyer, p. 37). Newmeyer contends that it was dissatisfaction with Chomsky's (1965) characterization of "competence" and "performance" which led linguists like Hymes to apply the notion of a speaker's "competence" to a far broader range of abilities than the innate knowledge of the structure of our language. Newmeyer believes that the term "communicative competence" "creates a pernicious ambiguity where none existed" (p. 38). And Taylor (1988), is even more dissatisfied with the term. His view is that much would be clarified if we did away with it completely as it has been so abused that it has lost all precise meaning. According to him, 
"the vague meaning that it does seem to have ('ability to perform') has no recognizable connection at all with competence as originally defined" (p. 166). I am inclined to agree with both Newmeyer and Taylor.

\section{THE NOTION OF "COMPETENCE"}

It seems that the individual words "communicative" or "nother-tongue" are not the source of confusion or dispute. Rather, it is the concept of "competence" which, in spite of an abundance of literature on the notion, remains ambiguous and therefore problematic. What then is meant by "competence" in a language? What do we know when we know a language? Exactly what does it mean to say that someone is a skilled, or a literate, or a fluent or a competent user of his mother-tongue? How, if at all, can the linguist help the teacher - or vice versa - to understand what is being tested when one tests an individual's mother-tongue competence?

To answer such questions, we need to know, of course, what linguists, psychologists and teachers have learned about the nature of language competence. Mellon (1981) says that "in order to appreciate the implications for teaching and testing that arise from the idea of mother-tongue competence, we must first be certain we understand that competence is an 'innate, invariant ability' and not a 'variable skill'" (p.28) At this point, I would again again like to remind you that what teachers call "competence", linguists generally view as as "performance". Mellon sees "performance" as "the variable use of competence in different language situations across the whole life span" (p.28). Competence, in contrast, he believes, should be "compared with other invariate human abilities, for example, the ability to walk upright. Every child who is not congenitally crippled leams to walk upright, learns without teaching, and learns equally well. In short, language competence is the same for all children, and offers the same springboard to school-fostered acquisition of performance skills" (p.28).

Many linguists and teachers might accept Mellon's description of competence as "innate" and "invariable", but his linking of these two adjectives with the word "ability" is what creates 
a problem. In fact, Taylor (1988) is of the opinion that much of the confusion surrounding the notion of competence has come about through the widespread interpretation of competence to include the idea of "ability".

Foremost among the causes of the confusion is perhaps the ordinary common sense use of the word "competence". For example, Collins English Dictionary (1986) cites as one of its meanings "the condition of being capable or able; ability" (p.332). There is thus a natural tendency to associate "ability" with "competence". However, it should be noted that Chomsky, the linguist who first drew attention to the distinction between competence and performance, has always excluded the idea of "ability" in his definition of competence:

Linguistic theory is primarily concerned with an ideal speaker-listener, in a completely homogeneous speech community ... We thus make a fundamental. distinction between "competence" (the speaker-hearer's knowledge of the language) and "performance", the actual use of language in concrete situations.

(Chomsky, 1965, pp.3-4)

From this definition, it is apparent that Chomsky is clearly concerned with idealization, and when he later (in the same work) refers to "intrinsic tacit knowledge" or "competence" (p.40), he establishes with absolute clarity the basic distinction between knowledge on the one hand, and the ability to use that knowledge on the other. In other words, "intrinsic tacit knowledge" clearly equates "competence" with "knowledge" and in so doing, excludes the idea of "ability".

Taylor (1988) claims that researchers like Campbell and Wales (1970) and Greene (1972) are responsible for the initial confusion in the field of linguistics. In addition to making the misleading connection between competence and ability, such researchers add to the confusion by interpreting Chomsky's definition of competence as having something to do with cognitive processes (p.150). For Chomsky, competence is clearly a state and not a process; it has nothing to do with "capacity" or "ability". Both in 1975 and in 1980, he very explicitly describes his conception of knowledge as a state: 
Knowledge, understanding, or belief is at a level more abstract than capacity ... The notions "capacity" and "family of dispositions" are more closely related to behavior and "language use" ... (1975, pp.23-24):

and:

To know a language, I an assuming, is to be in a certain mental state ... (I980, p. 48).

Chomsky explains that any attempt to characterize knowledge of language as a capacity or ability to do something, would mislead one to "conclude that behavior provides a criterion for the possession of knowledge," He argues convincingly that if, by contrast, "such knowledge is characterized in terms of mental state and structure, behavior simply provides evidence for possession of knowledge ..." (p.48). Chomsky, in other words, is concerned with the product rather than the process.

We see then that for Chomsky, competence is a static concept relating to individuals. The individuals he has in mind are ideal, monolingual native speakers. Taylor (1988) rightly asserts that later attempts to apply the concept to second-language learners are thus fraught with problems. His argument is that "if competence is something which characterizes individuals, it follows that it has an absolute quality and that no comparison is involved or is even possible" (p.153). In other words, like Mellon (1981), Taylor (1988) also regards competence as a property of the individual, similar to the colour of his or herr eyes or hair. It is something that is given, or innate; "it is biologically based" (p.153). These views certainly accord with the statement made by Chomsky (1980) : "Ultimately the study of language is part of human biology" (p.226).

Hymes (1972), like many linguists, finds Chomsky's view of competence lacking in that it has no place for sociocultural factors. His argument is that one of the things we know about language is how to use if appropriately. His actual words are " ... as some aspects of what Chomsky lumps together in a type of residual 'dustbin' (performance) are systematic, they 
can be described in the form of rules, and can thus be seen as a form of competence" (p. 272). His point is a valid one, and Chomsky himself acknowledges this later when, in addition to "grammatical competence" he recognizes "pragmatic competence", which he conceives as underlying the ability to make use of grammatical competence (Chomsky, 1980, p.59). In this sense, Hymes' argument is, in fact, a positive contribution to our understanding of what it means to know a language, because, as Taylor (1988) points out, "it certainly succeeds in tightening up the concept of performance by isolating from it aspects of language use that can be explained in terms of underlying knowledge which we can represent as a system of rules" (p.155).

Unfortunately though, when Hymes (1972) discusses the notion of competence, his argument is confused. As soon as he incorporates the idea of "ability", as is seen when he talks about "competence in production" (p.275) or "the specification of 'ability for use' as part of competence" (p.283) he, like Mellon (1981), Campbell and Wales (1970) and Greene (1972), is introducing an element which is not present in Chomsky's formulation of the idea. He might argue that he is merely "extending" Chomsky's idea of competence in order to cater for sociocultural factors, but he is in fact, introducing, a very "different" concept. The end result is that he subtly manages to create the impression that all aspects of language use fall within the domain of "competence", thus implying that they can be accounted for systematically in terms of rules. Chomsky (1975) is however, categoric on this point. He might recognize "pragmatic competence", but he also insists that "the 'creative aspect of language use' remains as much a mystery to us as it was to the Cartesians" (p. 138). With this I must agree.

The use of the term "competence" becomes even more confusing in psychological and educational literature. In psychology, competence is clearly associated with "skills" and "capacity", and there seems to be little suggestion of "mental state" or even "knowledge". For instance, Turner (1980), in a review of the psychological literature on competence, distinguishes between "cognitive competence" and "social competence" as follows: the first concerns, among other things, "those basic skills which are a precondition for subsequent skills", while the second involves "certain interpersonal problem-solving skills" (pp. 39 and 
43). Competence, in general, is seen as rejating to "an underlying organization of skills" (p.40). Interestingly, this inclusion of the notion of "skills" holds great appeal for those concerned with language teaching and testing. There is certainly no language syllabus or test specification which does not include in its aims the fostering and/or testing of skills. But, I must again point out that when we talk of testing language skills, we are more in line with Chomsky's (1965) idea of performance than with his concept of competence.

Given all these notions of competence, and there are many more, it is not surprising that we should feel frustration when attempting to define for ourselves what it is that we are testing when we claim to be testing mother-tongue competence - especially if we bear in mind that we need to turn to the disciplines discussed above for gaidance when making important decisions.

\section{HOW CAN WE CLARIFY THE CONFUSION?}

The question then arises whether there is in fact any way in which we can go about using the terms "competence" and "communicative competence" unambiguously or consistently? It would seem that most of the confusion occurs when competence is so-called "extended" to include process as well as product, function as well as form - in other words, when no distinction is lucidly made between states and dynamic processes. This comes about when we move beyond the original domain of Chomsky's (1965) "ideal speaker-hearer". Ironically it is the language teaching specialist, the applied linguist, who is obliged to do just this! The applied linguist must take a broader view of language and avail himself of the theories of other disciplines such as psychology and education. He is after all, dealing with real, live people - not ideal, non-existent speakers. He must take into account processes and functions. Nevertheless, although it is clear that Chomsky's notion of competence can only play a smail part in a language teacher's perception of teaching and testing, the fact that the term is used so widely and so diversely in so many different domains, indicates that there is still a need for some such distinction as the one which Chomsky makes between competence and performance. We must be able to distinguish, at some stage, between what a speaker "knows" and what he "does". For example, if we test a dumb person, is it fair to assume 
that he is not competent in his mother-tongue simply because he cannot "perform" with his mouth?

I believe that within the domain of language teaching, a common sense or logical solution to the problem might be simply to acknowledge that when a teacher applies a test, no matter what testing method or measuring instrument he uses, he is testing a pupil's performance not his competence. In short, I repeat that the term "communicative competence" is an unnecessary and confusing substitute for Chomsky's (1965) explicit definition of performance as "behavior"., "the use of knowledge of language" or "the actual use of language in concrete situations" (p. 4).

Another thing which makes me much happier with Chomsky's notion of performance is that besides his presupposition of competence for every instance of performance, he does provide for the many other factors that also contribute to performance. These include the speakerhearer's memory structure, his mode of organizing experience, his perceptual mechanisms, attention span and so forth (p. 3). In other words, in my view, he has made ample provision for all the factors which the various proponents of "communicative competence" wish to embrace in their confusing and unnecessary term. Of interest is the fact that although Chomsky has apparently indicated his awareness of the use of the term "communicative competence", according to Botha (1987), he has not commented directly on its merits or limitations (Botha, p. 252). His silence on the subject is perhaps deliberate : he has expressed himself explicitly and his definitions require no further clarification.

In view of the linguist's distinction between competence and performance, a teacher might well then argue that it is not necessary to pay attention to competence and that all their teaching and testing methods should concentrate on performance skills; skills that are teachable and testable. But, although linguists may claim that competence is not teachable, paradoxically, a number of vitally important guidelines for the teaching of performance skills arise from the linguist's view of competence. 


\section{HOW CAN LINGUISTICS ASSIST THE LANGUAGE TEACHER?}

As already intimated, the linguist views competence as partly innate and partly taken from the environment in a mysterious, as yet, not fully understood process. Fromkin and Rodman (1983) claim that it is acquired during the first four or five years of life, and that it is more or less the same for all children regardless of differences in intelligence, culture, or environment (p. 341). They explain that "it is this human capacity to acquire language that has led to the 'innateness hypothesis' of child language acquisition" (p. 342). Thus, when linguists use the term "mother-tongue competence" they are not referring to observable instances of language use like reading a novel, writing an essay or delivering a specch. They are referring to a complex network of unconscious knowledge within our minds, knowledge that informs such language use, that makes such usage possible. There are many elements in this network of unconscious knowledge. As Mellon (1981) observes, a complete list "would read like a litany of linguistic jargon" (p. 27). It is not possible to discuss all the components of this network of unconscious knowledge. What is of importance though, is to recognize that such components have been identified by linguists and that their identification serves to illustrate the truism that to know a language is to know a great deal more than we realize we know.

Mother-tongue competence may sound abstract and technical in linguistic terminology, but all children from kindergarten on possess it. As Mellon (1981) says, they "acquire it uniformly and wholly as a result of learning processes innately scheduled in every child" (p.28), Any Grade 1 teacher will agree that when children arrive at school for their first formal tuition, they already know the principles of the word order in their mother-tongue; they already know semantic relationships, not their names, but what they are. They already have lexical features ready for use in subsequent vocabulary leaming; they already use sentence-combining transformations in their speech, though not nearly as many as they will use as adults; and they already possess the principle of logical conjunction. The most important thing to remember about mother-tongue competence is simply that it exists. If we keep this in mind, we will appreciate that in the teaching and testing of language, the appropriate pedagogy for all children, not merely "gifted" children, is one which will lead 
students into increasingly mature uses of the linguistic system they already possess.

To re-iterate, given the distinction between competence and performance, in the realm of schooling, it is not really mother-tongue competence that we endeavour to measure, but rather the variable skills of mother-tongue performance. If I had the time, I would really like to discuss these variable skills and their complex implications for teaching and testing. Just by way of a very short example for instance, can anyone here explain what exactly the testing of so-called simple "reading comprehension" entails? Although I have written two lengthy chapters on the subject, I can provide no definitive answer. All I can say with certainty is that reading comprehension is by no means a passive skill. It requires high-level language ability, including the creative ability to construct meaning from text. As Schroen (1990) puts it, "(reading comprehension) involves being able to follow a logical sequence, to predict and anticipate, to reason from cause to effect, to make inferences and deductions from given evidence, to evaluate and compare, to distinguisl between fact and opinion, and so on" (p. 38). Such assertions regarding the complex skills inherent in reading alone, which is only one of the four language modes, again make us aware of how difficult a task it is to explain what it means to be competent in one's mother tongue.

\section{CONCLUSION}

It seems then that I conclude on a very inconclusive note. But, such is the nature of language. I hope I have at least conveyed my belief that in an already complex field such as language teaching and testing, we should strive for clarity in terminology - not add to the complexity with new ambiguous terms. I conclude by re-emphasizing that when we claim to be testing competence, be it mother-tongue competence or communicative competence, we are in reality, testing performance. After all, as Botha (1987) puts it, "even the linguist, on Chomsky's (1980, p. 225) view, has no other way of studying competence other than through performance" (p. 102).

It is not Chomsky who confuses us. It is those who have somehow managed to shroud his very clear distinction in obscurity. Indeed, this is all very reminiscent of Einstein's theory 
of relativity. When I read the theory as originally postulated by the genius, it seens so beautifully clear, but when I try to unravel what he means according to those who have set out to "explain" his hypothesis, then I feel like a total ignoramus. Like Pauline Rea (1985), who feels completely confused because of the "existence of (all the) ill-defined criteria abundant in the literature on language testing" (p. 20), I too end up by not knowing what a "mother-tongue communicative competence" test is supposed to look like! Had I the time, I would however, with Chomsky's views in mind, be able to offer more confident and concrete guidelines as to the make-up of a "mother-tongue perfornance" test. 


\section{BIBLIOGRAPHY}

Alderson, J.C. 1990.

Botha, R.P. 1987.

Campbell, R. and

Wales, R. 1970.

Canale, M. and

Swain, M. 1980.

Chomsky, N. 1965.

Chomsky, N. 1975.

Chomsky, N. 1980.

Collins Dictionary of

the English Language. 1986.

Fromkin, V. and

Rodman, R. 1983.

Greene, J. 1972.

Hymes, D.H. 1971.

Hymes, D.H. 1972.
Judgements in language testing, version three. Thessaloniki, Greece: Paper presented at the Meeting of the Ninth World Congress of Applied Linguistics, 15-21 April, 13p.

The generative garden game. Stellenbosch : SPIL PLUS 11.

"The study of language acquisition". In J. Lyons (ed.) New horizons in Linguistics. Harmondsworth, Middlesex: Penguin.

"Theoretical bases of communicative approaches to second language teaching and testing", Applied Linguistics, Vol. 1, No. 1, pp. 1-47.

Aspects of the theory of syntax. Cambridge, Mass., The MIT Press.

Reflections on language. New York : Pantheon.

Rules and representations. Oxford: Blackwell.

Collins Dictionary of the English Language. P. Hanks, (ed.) London : Collins. Second edition.

An introduction to language. 2nd ed. New York: Holt, Rinehart and Winston.

Psycholinguistics. Harmondsworth, Middlesex: Penguin.

"Competence and performance in linguistic theory". In R. Huxley and E. Ingram (eds.) Language acquisition: models and methods. New York: Academic Press.

"On communicative competence". In J.B. Pride and J. Holmes (eds.) Sociolinguistics. Middlesex, England : Penguin Books. 
Mellon, J.C. 1981.

Newmeyer, F. 1983.

Pit Corder, S. 1973.

Rea, P.M. 1985.

Richards, J., Platt, J. and Weber, H. 1985.

Schroenn, M.B. 1990.

Taylor, D. 1988.

Tumer, J. 1980.
"Language Competence". In C.R. Cooper, (ed.). The nature and measurement of competency in English. Urbana,llinois: National Council of Teachers of English. pp. 21-64.

Grammatical theory. Its limits and its possibilities. New York: Academic Press.

Introducing applied linguistics. Harmondsworth, Middlesex: Penguin.

"Language testing and the communicative language teaching curriculum". In Y.P. Lee, et al,, (eds). New Directions in Language Testing. Oxford : Pergamon Press.

Longman dictionary of Applied Linguistics. Essex : Longman Group Limited.

"Developing thinking and problem solving skills", in Res Curriculi : Journal of the curriculum affairs section Natal Education Department. 1, November.

"The meaning and use of the term 'competence' in linguistics and applied linguistics", in Applied linguistics, Vol. 9, No. 2. pp. 148-168.

"The development of competence", in Educational review, 2: 37-46. 